Tomasz Kołodziej

Instytut Socjologii

Uniwersytet Zielonogórski

\title{
ZMIANY SYTUACJI ZATRUDNIENIA ORAZ MIEJSCA ZATRUDNIENIA POLAKÓW W ŚWIETLE BADAŃ PANELOWYCH POLPAN
}

\section{Wprowadzenie}

Niniejszy tekst dotyczy problematyki zmian sytuacji zatrudnienia oraz miejsc zatrudnienia Polaków w latach 1998-2003. Sytuacja pracy osób, które w okresie przejścia z gospodarki centralnie planowanej do wolnorynkowej wchodziły na rynek pracy, zależała od zachodzących w tym okresie procesów. Odejście od polityki pełnego zatrudnienia, uelastycznienie rynku pracy, wzrost roli konkurencji oraz utowarowienie pracy stworzyły nową rzeczywistość, w której funkcjonowały nie tylko jednostki, ale całe grupy zawodowe (por. Drozdowski 2002: 90-142). Struktura społeczna, analizowana z punktu widzenia zagadnień związanych z pracą, podlegała w tym okresie zmianom, których tempo oraz kierunek w znacznej mierze stały się nieprzewidywalne. „Przyśpieszenie, jakiego na przełomie wieków (XX i XXI) nabrały procesy polityczne i gospodarcze w świecie, zwłaszcza w Europie Środkowo-Wschodniej, sprawiło, że sferę pracy zarobkowej dotknęły radykalne zmiany. Zasoby pracy uległy znacznemu ograniczeniu, a sama praca... nabrała nowych właściwości i znaczeń. Coraz liczniejsi pracownicy, bez względu na wiek, staż pracy i kwalifikacje zaczęli doświadczać trudności i niepokój związane z adaptacją do nieustannie zmieniających się wymagań rynku pracy" (Janicka 2007: 158). Rozwój sektora prywatnego w gospodarce oraz większa niż przed 1989 r. mobilność pracowników doprowadziły do różnicowania się ich ścieżek zatrudnienia. 
Próba zaobserwowania zmian sytuacji zatrudnienia oraz miejsca zatrudnienia, jakie wystąpiły w karierach zawodowych Polaków, wymaga specyficznego rodzaju danych. Badania przekrojowe prowadzone przez ośrodki badawcze takie jak CBOS pozwalają dostrzec zmiany w liczebności kategorii społecznych. Podstawowym ograniczeniem tego typu pomiarów jest brak możliwości analizy kierunku i skali przepływów jednostek pomiędzy badanymi kategoriami, co jest efektem realizacji badań na innej, za każdym razem, próbie respondentów. Odpowiedzi na pytania o siłę i kierunek przepływu dostarczyć mogą dane zebrane $\mathrm{w}$ badaniach panelowych. Badania panelowe przeprowadzane są w tej samej grupie badanych w określonych interwałach czasowych ${ }^{1}$, dzięki czemu można ustalić zależności przyczynowo-skutkowe oraz zmiany badanych cech i procesów w czasie (por. Babbie 2004: 123-124). Dane, które posłużyły do przeprowadzenia przedstawionych w tekście analiz, pochodzą z Polskiego Badania Panelowego POLPAN, które koncentruje się na strukturze i ruchliwości społecznej. Panel ten realizowany jest przez Zespół Porównawczych Analiz Nierówności społecznych funkcjonujący w Instytucie Filozofii i Socjologii Polskiej Akademii Nauk (www.polpan.org). Badanie przeprowadzane jest cyklicznie od $1988 \mathrm{r}$. w pięcioletnich interwałach. W 2008 r., w którym zrealizowana została ostatnia tura badania, próba panelowa liczyła 933 respondentów, którzy brali udział we wszystkich pięciu falach, począwszy od $1988 \mathrm{r}$.

\section{Problemy badawcze i definicyjne}

Przeprowadzone analizy służą odnalezieniu odpowiedzi na następujące problemy:

1. Jakim zmianom, pomiędzy rokiem 1998 a 2008, uległa sytuacja zatrudnienia respondentów?

2. Do jakich zmian doszło pomiędzy kategoriami miejsca zatrudnienia badanej grupy Polaków?

Ze względu na wielość definicji stosowanych w tekście pojęć, analizy należy poprzedzić krótkim wprowadzeniem objaśniającym przyjęte znaczenie niektórych terminów (analizowanych zmiennych):

\footnotetext{
${ }^{1}$ Uwaga autora - badania panelowe borykają się z problemem „wykruszania się” próby, co jest skutkiem rezygnacji respondentów z dalszego udziału w badaniach, braku możliwości odszukania respondenta w kolejnej turze, śmierci badanego itd. W zależności od założeń metodologicznych próba może być uzupełniana o nowych respondentów lub kontynuowana jedynie na starej próbie.
} 
1. Poprzez pracę zarobkową rozumie się ,,względnie stałe wykonywanie zajęć wymagających określonych umiejętności w celu uzyskania dochodu" (Janicka 2007: 157-158).

2. Miejsce zatrudnienia rozumiane jest jako wykonywanie przez respondenta przez co najmniej trzy miesiące:

a) najemnej pracy zarobkowej w sektorze państwowym,

b) najemnej pracy zarobkowej w sektorze prywatnym,

c) najemnej pracy w zagranicznej firmie prywatnej,

d) najemnej pracy w gospodarstwie rolnym,

e) najemnej pracy dorywczej (niemającej regularnego charakteru),

f) pracy na własny rachunek.

3. Poprzez sytuację pracy rozumie się:

a) wykonywanie pracy zarobkowej w jednym miejscu zatrudnienia (na podstawie jednej umowy dowolnego rodzaju, zawartej na więcej niż trzy miesiące),

b) posiadanie więcej niż jednego miejsca zatrudnienia (więcej niż jednej umowy dowolnego typu, zawartej na czas dłuższy niż trzy miesiące),

c) przebywanie na emeryturze lub rencie,

d) zajmowanie się domem,

e) posiadanie statusu bezrobotnego,

f) inne - jest agregatem sytuacji, gdy respondent nie pracował, ale nie posiadał statusu bezrobotnego, nie pracował, ponieważ się uczył, był chory lub musiał opiekować się rodzicami, przebywał na urlopie macierzyńskim, w więzieniu lub odbywał służbę wojskową.

Przyjęte znaczenia terminów „miejsce zatrudnienia” oraz „sytuacja pracy” są konsekwencją obowiązujących w POLPAN-ie terminów badawczych.

\section{Charakterystyka próby badawczej}

Analizy przeprowadzone zostały dla 933 respondentów, którzy wzięli udział we wszystkich pięciu turach badania (lata 1988, 1993, 1998, 2003 oraz 2008). Ze względu na dostępność danych, a precyzyjniej niemożność analizy niektórych zmiennych z dostępnej bazy danych, wykorzystano dane pochodzące z 1998, 2003 oraz 2008 r. 
Tabela 1. Ogólna charakterystyka próby badawczej

\begin{tabular}{|l|c|c|}
\hline \multicolumn{3}{|c|}{ Struktura próby według płci } \\
\hline Mężczyźni & 438 & $46,9 \%$ \\
\hline Kobiety & 495 & $53,1 \%$ \\
\hline \multicolumn{3}{|c|}{ Struktura próby według roku urodzenia } \\
\hline $1964-1973$ & 55 & $5,9 \%$ \\
\hline $1954-1963$ & 276 & $29,6 \%$ \\
\hline $1944-1953$ & 306 & $32,8 \%$ \\
\hline Do 1943 & 296 & $31,7 \%$ \\
\hline
\end{tabular}

Źródło: opracowanie własne na podstawie danych POLPAN.

Struktura próby jest konsekwencją panelowego charakteru badania. Reprezentatywność próby, którą charakteryzowało się badanie w roku 1988, została zaburzona poprzez utratę możliwości przebadania części respondentów w kolejnych turach badania oraz starzenie się grupy panelowej. Do utraty kontaktu z respondentem, a więc i wypadnięcia osoby z próby badawczej, dochodzi na skutek choroby respondenta, zmiany miejsca zamieszkania i niemożności ustalenia nowego adresu, rezygnacji respondenta itd. Starzenie się próby badawczej jest naturalnym procesem podczas badań panelowych. W przeciwieństwie do badań przekrojowych, w jakich za każdym razem losowana jest nowa próba, która uwzględnia wszystkie kategorie wiekowe, panel dotyczy jednej i tej samej grupy ludzi. Respondenci, którzy podczas badania w 1998 r. mieli 25 lat, w roku 2003 byli już 30-latkami. Tak więc struktura wiekowa grupy zmienia się w czasie. Sytuację tę obrazują dane przedstawione w tabeli 2. Jakkolwiek próba badawcza była uzupełniana o nowych respondentów, to brak informacji na temat ich wcześniejszych losów uniemożliwił uwzględnienie ich w analizach.

Dane zawarte w tabeli 2 pokazują np., że grupa respondentów w wieku 25-34 lata, która uczestniczyła w badaniu w 1998 r., nie występowała już w roku 2003. Osoby z tej grupy były w 2003 r. w wieku 30-39 lat, a w 2008 r. 35-44 lata. Analogicznie przesunięcie dotyczy wszystkich grup wiekowych analizowanych w 1998 r. Jednocześnie, ze względu na to, że badanie powtarzane jest co pięć lat, natomiast respondenci pogrupowani zostali na podstawie dziesięcioletnich interwałów, zmieniają się również liczebności danych kategorii wiekowych. 
Tabela 2. Struktura wieku próby badawczej obejmującej respondentów pracujących (w podziale na tury badania)

\begin{tabular}{|c|c|c|c|}
\hline Wyszczególnienie & Tura 1998 & Tura 2003 & Tura 2008 \\
\hline \multirow{3}{*}{$\begin{array}{c}\text { Wiek w latach } \\
\text { (liczba badanych N) }\end{array}$} & $25-34(41)$ & $30-39$ lat (45) & 35-44 lata (45) \\
\cline { 2 - 4 } & $35-44(231)$ & $40-49$ lat (217) & 45-54 lata (232) \\
\cline { 2 - 4 } & $45-54(232)$ & $50-59$ lat (159) & 55-64 lata (139) \\
\hline $\begin{array}{c}\text { Wiek w latach } \\
\text { (procent całej próby) }\end{array}$ & $55+(71)$ & $60+(24)$ & $65+(16)$ \\
\hline
\end{tabular}

Źródło: opracowanie własne na podstawie danych POLPAN.

\section{Analiza zmian sytuacji zatrudnienia}

Obliczenia dotyczące sytuacji zatrudnienia oraz zmian, jakim ona podlegała, wykonane zostały dla wszystkich 933 respondentów tworzących próbę badawczą.

Prezentowane wyniki ukazują zmianę sytuacji zawodowej badanych osób pomiędzy kolejnymi turami badania - 1998 i 2003 (tabela 3) oraz 2003 i 2008 (tabela 4). Na uwagę zasługują przede wszystkim dane dotyczące pracujących respondentów, których sytuacja nie uległa zmianie. Brak zmiany w tym wypadku może oznaczać z jednej strony stabilną sytuację zawodową respondenta, co nawiązując do tez Ulricha Becka zawartych w książce Społeczeństwo ryzyka, ma istotne znaczenie dla funkcjonowania jednostki w społeczeństwie i świadczy o posiadaniu przez respondentów odpowiednich kwalifikacji, by pracę zdobyć i utrzymać, zwłaszcza w sytuacji tzw. elastycznego rynku pracy (Beck 2002: 208-231). $Z$ drugiej jednak strony ten poziom analiz nie informuje nas, czy i ile razy $\mathrm{w}$ badanym okresie respondent zmienił miejsce pracy oraz czy ta zmiana miała charakter awansu czy degradacji zawodowej. Ponadto istotne z punktu widzenia sytuacji ekonomicznej jest to, co dzieje się z respondentami, którzy nie posiadają pracy, a którzy potencjalnie mogą ją podjąć. W tym wypadku przemieszczenie się respondentów z tej kategorii do kategorii osób posiadających pracę świadczyć może o poprawie sytuacji gospodarczej w szerszym kontekście i zwiększeniu puli miejsc na rynku pracy. 
Tabela 3. Zmiany sytuacji zatrudnienia respondentów z próby panelowej pomiędzy 1998 a $2003 \mathrm{r}$.

\begin{tabular}{|c|c|c|c|c|c|c|}
\hline Sytuacja & \multicolumn{6}{|c|}{2003} \\
\hline 1998 & $\begin{array}{l}\text { jedna } \\
\text { praca }\end{array}$ & $\begin{array}{c}\text { więcej } \\
\text { niż jedna } \\
\text { praca }\end{array}$ & $\begin{array}{c}\text { emerytura/ } \\
\text { renta }\end{array}$ & $\begin{array}{c}\text { zajmowa- } \\
\text { nie się } \\
\text { domem }\end{array}$ & $\begin{array}{l}\text { bezro- } \\
\text { botny }\end{array}$ & $\begin{array}{c}\text { inna } \\
\text { sytuacja }\end{array}$ \\
\hline Jedna praca & $\begin{array}{c}305 \\
(62 \%)\end{array}$ & $\begin{array}{c}23 \\
(4,7 \%) \\
\end{array}$ & $\begin{array}{c}12 \\
(2,4 \%)\end{array}$ & $\begin{array}{c}1 \\
(0,2 \%) \\
\end{array}$ & $\begin{array}{c}107 \\
(21,7 \%) \\
\end{array}$ & $\begin{array}{c}44 \\
(8,9 \%) \\
\end{array}$ \\
\hline $\begin{array}{c}\text { Więcej niż jedna } \\
\text { praca }\end{array}$ & $\begin{array}{c}45 \\
(54,2 \%) \\
\end{array}$ & $\begin{array}{c}28 \\
(33,7 \%) \\
\end{array}$ & $\begin{array}{c}2 \\
(2,4 \%) \\
\end{array}$ & 0 & $\begin{array}{c}4 \\
(4,8 \%) \\
\end{array}$ & $\begin{array}{c}4 \\
(4,8 \%) \\
\end{array}$ \\
\hline Emerytura/renta & $\begin{array}{c}10 \\
(8,1 \%) \\
\end{array}$ & 0 & $\begin{array}{c}5 \\
(4,1 \%) \\
\end{array}$ & 0 & $\begin{array}{c}80 \\
(65 \%)\end{array}$ & $\begin{array}{c}28 \\
(22,8 \%)\end{array}$ \\
\hline $\begin{array}{c}\text { Zajmowanie się } \\
\text { domem }\end{array}$ & $\begin{array}{c}12 \\
(6,5 \%) \\
\end{array}$ & 0 & $\begin{array}{c}15 \\
(8,2 \%) \\
\end{array}$ & $\begin{array}{c}5 \\
(2,7 \%) \\
\end{array}$ & $\begin{array}{c}112 \\
(60,9 \%)\end{array}$ & $\begin{array}{c}40 \\
(21,7 \%) \\
\end{array}$ \\
\hline Bezrobotny & $\begin{array}{c}4 \\
(33,3 \%)\end{array}$ & 0 & $\begin{array}{c}2 \\
(16,7 \%)\end{array}$ & 0 & $\begin{array}{c}4 \\
(33,3 \%)\end{array}$ & $\begin{array}{c}2 \\
(16,7 \%) \\
\end{array}$ \\
\hline Inna sytuacja & $\begin{array}{c}16 \\
(41 \%)\end{array}$ & $\begin{array}{c}2 \\
(5,1 \%)\end{array}$ & 0 & 0 & $\begin{array}{c}13 \\
(33,3 \%)\end{array}$ & $\begin{array}{c}8 \\
(20,5 \%)\end{array}$ \\
\hline
\end{tabular}

Źródło: opracowanie własne na podstawie danych POLPAN.

Wyniki ukazują wysoki poziom niestabilności sytuacji zatrudnienia. W trakcie 10 lat, których dotyczą dane, struktura zatrudnienia zmieniła się znacznie. W przypadku okresu pomiędzy 1998 a 2003 r. wyróżnić możemy cztery zasadnicze kierunki zmian:

1. Istotne przesunięcia z kategorii osób wykonujących jedną pracę do kategorii osób posiadających status bezrobotnego - 21,7\%.

2. Znaczące przesunięcie $\mathrm{z}$ kategorii osób wykonujących dwie prace do kategorii osób wykonujących jedną pracę zarobkową - 54,2\%.

3. Bardzo duży odpływ osób, których głównym zajęciem było zajmowanie się domem do kategorii osób bezrobotnych - 60,9\%.

4. Bardzo duże przesunięcie z kategorii emerytów lub rencistów do kategorii osób bezrobotnych $-65 \%$.

Okres pomiędzy rokiem 2003 a 2008 również odznaczał się dużą ruchliwością respondentów. Dotyczyła ona jednak zupełnie innego kierunku niż w poprzednim pięcioleciu. Ten okres scharakteryzować można przede wszystkim poprzez: 
1) przejścia znacznego odsetka respondentów mających status bezrobotnego na emeryturę lub rentę $-79,4 \%$,

2) przesunięcie się istotnego odsetka osób z kategorii inna sytuacja do kategorii emerytura/ renta $-77 \%$.

Tabela 4. Zmiany sytuacji zatrudnienia respondentów z próby panelowej pomiędzy 2003 a $2008 \mathrm{r}$.

\begin{tabular}{|c|c|c|c|c|c|c|}
\hline Sytuacja & \multicolumn{6}{|c|}{2008} \\
\hline 2003 & $\begin{array}{l}\text { jedna } \\
\text { praca }\end{array}$ & $\begin{array}{c}\text { więcej niż } \\
\text { jedna } \\
\text { praca }\end{array}$ & $\begin{array}{c}\text { emerytura } \\
\text { /renta }\end{array}$ & $\begin{array}{c}\text { zajmowa- } \\
\text { nie się } \\
\text { domem }\end{array}$ & $\begin{array}{l}\text { bezro- } \\
\text { botny }\end{array}$ & $\begin{array}{c}\text { inna } \\
\text { sytuacja }\end{array}$ \\
\hline Jedna praca & $\begin{array}{c}282 \\
(71,9 \%)\end{array}$ & $\begin{array}{c}31 \\
(7,9 \%)\end{array}$ & $\begin{array}{c}63 \\
(16,1 \%)\end{array}$ & $\begin{array}{c}1 \\
(0,3 \%)\end{array}$ & $\begin{array}{c}11 \\
(2,8 \%)\end{array}$ & $\begin{array}{c}4 \\
(1 \%)\end{array}$ \\
\hline $\begin{array}{l}\text { Więcej niż } \\
\text { jedna praca }\end{array}$ & $\begin{array}{c}27 \\
(50,9 \%)\end{array}$ & $\begin{array}{c}21 \\
(39,6 \%)\end{array}$ & $\begin{array}{c}3 \\
(5,7 \%)\end{array}$ & 0 & $\begin{array}{c}2 \\
(3,8 \%)\end{array}$ & 0 \\
\hline $\begin{array}{l}\text { Emerytura/ } \\
\text { renta }\end{array}$ & $\begin{array}{c}4 \\
(11,1 \%)\end{array}$ & 0 & $\begin{array}{c}31 \\
(86,1 \%)\end{array}$ & 0 & $\begin{array}{c}1 \\
(2,8 \%)\end{array}$ & 0 \\
\hline $\begin{array}{l}\text { Zajmowanie } \\
\text { się domem }\end{array}$ & $\begin{array}{c}1 \\
(16,7 \%)\end{array}$ & 0 & $\begin{array}{c}5 \\
(83,3 \%)\end{array}$ & 0 & 0 & 0 \\
\hline Bezrobotny & $\begin{array}{c}45 \\
(14,1 \%) \\
\end{array}$ & $\begin{array}{c}1 \\
(0,3 \%) \\
\end{array}$ & $\begin{array}{c}254 \\
(79,4 \%) \\
\end{array}$ & $\begin{array}{c}8 \\
(2,5 \%) \\
\end{array}$ & $\begin{array}{c}9 \\
(2,8 \%) \\
\end{array}$ & $\begin{array}{c}3 \\
(0,9 \%) \\
\end{array}$ \\
\hline Inna sytuacja & $\begin{array}{c}19 \\
(15,1 \%)\end{array}$ & $\begin{array}{c}1 \\
(0,8 \%)\end{array}$ & $\begin{array}{c}97 \\
(77 \%)\end{array}$ & $\begin{array}{c}2 \\
(1,6 \%)\end{array}$ & $\begin{array}{c}2 \\
(1,6 \%)\end{array}$ & $\begin{array}{c}5 \\
(4 \%)\end{array}$ \\
\hline
\end{tabular}

Źródło: opracowanie własne na podstawie danych POLPAN.

Należy również zwrócić uwagę na fakt, że największą stabilnością odznaczała się w analizowanych okresach jedynie sytuacja osób, które wykonywały jedną pracę zarobkową. Potencjalnych wyjaśnień tej sytuacji może być kilka, z których w odniesieniu do dokonywanych analiz warto przytoczyć dwa. Po pierwsze, mobilność tej grupy respondentów może dokonywać się wewnątrz kategorii - czyli np. zmiany jednego miejsca pracy na inne. Na podstawie tak zagregowanych danych tego zjawiska jednak nie da się dostrzec. Po drugie, sektor, w jakim pracują respondenci, może sprzyjać bezpieczeństwu zatrudnienia - ta teza zostanie zweryfikowana $\mathrm{w}$ dalszej części artykułu. $\mathrm{W}$ tym miejscu równie 
istotna wydaje się być sytuacja osób, które w którymkolwiek z analizowanych momentów wykonywały więcej niż jedną pracę zarobkową. Wprawdzie zarówno pomiędzy 1998 i 2003 r., jak i pomiędzy latami 2003 i 2008 ponad połowa z nich przesunęła się do kategorii ,jedna praca”, co de facto oznacza utratę przynajmniej jednego miejsca zatrudnienia, to $\mathrm{w}$ dalszym ciągu blisko $90 \% \mathrm{z}$ nich pozostaje aktywnych zawodowo. Biorąc pod uwagę liczebność tej grupy, jest ona najmniej zagrożona bezrobociem spośród wszystkich analizowanych kategorii.

Warto postawić także pytanie o przyczyny zaobserwowanych kierunków zmian. Uśrednione bezrobocie roczne w Polsce w roku 1998 wynosiło 9,9\%, w roku 2003 wzrosło ono do 19,9\%, a w roku 2008 spadło do 9,8\%². Również w badanej próbie zjawisko wzrostu bezrobocia w tym okresie jest wyraźnie widoczne. Jednocześnie, śledząc kierunek ruchliwości w kategorii bezrobotnych respondentów, należy założyć, że w 2003 r. bezrobocie dotknęło przede wszystkim starszych respondentów, którzy już w 2008 r. znaleźli się w grupie osób będących na emeryturze lub rencie. Warto również zauważyć, że $65 \%$ z licznej w 1998 r. grupy emerytów i rencistów znalazło się w 2003 r. w kategorii bezrobotni. Jest to zapewne wynik wprowadzenia obostrzeń prawnych oraz kontroli przeprowadzanych przez Zakład Ubezpieczeń Społecznych, które doprowadziły do tego, że liczba przyznanych rent spadła ze 155 tys. w roku 1997 do 67 tys. w roku 2003 (http://www.pracuj.pl/Sprawni-w-pracy-praca-renta-apraca.htm).

\section{Analiza zmian miejsca zatrudnienia}

Ta część artykułu dotyczy jedynie respondentów, którzy posiadali pracę w każdej kolejnej turze badania, stąd też mogą wystąpić rozbieżności w liczbie respondentów pomiędzy poszczególnymi turami badania. Różnice te wynikają z faktu przechodzenia części respondentów na emeryturę (rentę), utraty pracy lub zajmowania się domem. Analiza danych dotyczących miejsca zatrudnienia przedstawiona została $\mathrm{w}$ podziale na tury badania, w postaci tabel krzyżowych obrazujących zmiany pomiędzy poszczególnymi kategoriami.

Postępujący od początku lat 90. intensywny rozwój sektora prywatnego znalazł odbicie również w analizowanych danych, co pokazują dane w tabeli 5.

\footnotetext{
${ }^{2}$ Obliczenia własne na podstawie miesięcznych danych GUS, http://www.stat.gov.pl/gus/5840 _677_PLK_HTML.htm.
} 
Tabela 5. Miejsce zatrudnienia respondentów, liczbowy i procentowy udział w próbie w kolejnych turach badania

\begin{tabular}{|c|c|c|c|c|c|c|}
\hline \multirow{2}{*}{ Miejsce zatrudnienia } & \multicolumn{5}{|c|}{ Tury POLPAN } \\
\cline { 2 - 7 } & \multicolumn{2}{|c|}{1998} & \multicolumn{2}{|c|}{2003} & \multicolumn{2}{|c|}{2008} \\
\hline A & 284 & $49,4 \%$ & 190 & $42,8 \%$ & 146 & $33,8 \%$ \\
\hline B & 19 & $3,3 \%$ & 20 & $4,5 \%$ & 31 & $7,2 \%$ \\
\hline C & 91 & $15,8 \%$ & 79 & $17,8 \%$ & 104 & $24,1 \%$ \\
\hline D & 102 & $17,7 \%$ & 78 & $17,6 \%$ & 75 & $17,4 \%$ \\
\hline E & 61 & $10,6 \%$ & 51 & $11,5 \%$ & 50 & $11,6 \%$ \\
\hline F & 18 & $3,1 \%$ & 26 & $5,9 \%$ & 26 & $6 \%$ \\
\hline
\end{tabular}

A - praca najemna w firmach/instytucjach państwowych, B - praca najemna w firmach zagranicznych, $\mathrm{C}$ - praca najemna w firmach prywatnych, D - praca w gospodarstwie rolnym, $\mathrm{E}$ - praca we własnej firmie/na własny rachunek, $\mathrm{F}$ - prace dorywcze/nieregularne.

Źródło: opracowanie własne na podstawie danych POLPAN.

Tabela 6. Zmiany miejsca zatrudnienia respondentów pomiędzy 1998 a 2003 r.

\begin{tabular}{|c|c|c|c|c|c|c|}
\hline Miejsce & \multicolumn{6}{|c|}{2003} \\
\hline Tura 1998 & A2 & B2 & $\mathrm{C} 2$ & D2 & E2 & $\mathrm{F} 2$ \\
\hline A & $\begin{array}{c}168 \\
(81,6 \%) \\
\end{array}$ & $\begin{array}{c}4 \\
(1,9 \%)\end{array}$ & $\begin{array}{c}25 \\
(12,1 \%)\end{array}$ & 0 & $\begin{array}{c}6 \\
(2,9 \%) \\
\end{array}$ & $\begin{array}{c}3 \\
(1,5 \%)\end{array}$ \\
\hline B & 0 & $\begin{array}{c}10 \\
(66,7 \%) \\
\end{array}$ & $2(13,3 \%)$ & $1(6,7 \%)$ & $\begin{array}{c}1 \\
(6,7 \%) \\
\end{array}$ & $\begin{array}{c}1 \\
(6,7 \%) \\
\end{array}$ \\
\hline $\mathrm{C}$ & $\begin{array}{c}12 \\
(20,3 \%) \\
\end{array}$ & $\begin{array}{c}3 \\
(5,1 \%) \\
\end{array}$ & $\begin{array}{c}37 \\
(62,7 \%) \\
\end{array}$ & $1(1,7 \%)$ & $\begin{array}{c}2 \\
(3,4 \%) \\
\end{array}$ & $\begin{array}{c}4 \\
(6,8 \%) \\
\end{array}$ \\
\hline D & 0 & 0 & $2(3,1 \%)$ & $\begin{array}{c}60 \\
(92,3 \%)\end{array}$ & $\begin{array}{c}2 \\
(3,1 \%)\end{array}$ & $\begin{array}{c}1 \\
(1,5 \%)\end{array}$ \\
\hline E & $\begin{array}{c}1 \\
(2,1 \%) \\
\end{array}$ & $\begin{array}{c}1 \\
(2,1 \%) \\
\end{array}$ & $2(4,3 \%)$ & $2(4,3 \%)$ & $\begin{array}{c}36 \\
(76,6 \%) \\
\end{array}$ & $\begin{array}{c}5 \\
(10,6 \%) \\
\end{array}$ \\
\hline F & 0 & $\begin{array}{c}1 \\
(12,5 \%)\end{array}$ & $1(12,5 \%)$ & $3(37,5)$ & 0 & $\begin{array}{c}3 \\
(37,5 \%)\end{array}$ \\
\hline
\end{tabular}

Oznaczenia jak w tabeli 5.

Źródło: opracowanie własne na podstawie danych POLPAN. 
Wyraźnie widać stopniowo zmniejszający się udział pracowników sektora państwowego $\mathrm{w}$ ogóle pracujących respondentów. Jednocześnie zauważyć należy wzrost udziału respondentów zatrudnionych w firmach prywatnych oraz wykonujących prace nieregularne i dorywcze. Niewielki wzrost zanotowano również w przypadku zatrudnionych w prywatnych firmach zagranicznych oraz wśród prowadzących własne firmy. Istotny w tym kontekście wydaje się fakt dużej stabilności zatrudnienia wśród pracujących w gospodarstwach rolnych, co częściowo może być wyjaśnieniem stabilności kategorii osób wykonujących jedną pracę, o której była mowa w poprzedniej części artykułu. Tabele 6 oraz 7 przedstawiają zmiany miejsca zatrudnienia respondentów w badanych okresach.

Tabela 7. Zmiany miejsca zatrudnienia respondentów pomiędzy 2003 a 2008 r.

\begin{tabular}{|c|c|c|c|c|c|c|}
\hline Miejsce & \multicolumn{6}{|c|}{2008} \\
\hline 2003 & A2 & B2 & C2 & D2 & E2 & $\mathrm{F} 2$ \\
\hline A & $\begin{array}{c}123 \\
(77,4 \%)\end{array}$ & $\begin{array}{c}6 \\
(3,8 \%)\end{array}$ & $\begin{array}{c}22 \\
(13,8 \%)\end{array}$ & $\begin{array}{c}3 \\
(1,9 \%)\end{array}$ & $\begin{array}{c}2 \\
(1,3 \%)\end{array}$ & $\begin{array}{c}3 \\
(1,9 \%)\end{array}$ \\
\hline B & $\begin{array}{c}1 \\
(5 \%) \\
\end{array}$ & $\begin{array}{c}15 \\
(75 \%) \\
\end{array}$ & $\begin{array}{c}4 \\
(20 \%) \\
\end{array}$ & 0 & 0 & 0 \\
\hline $\mathrm{C}$ & $14(22,2 \%)$ & $\begin{array}{c}4 \\
(6,3 \%) \\
\end{array}$ & $\begin{array}{c}39 \\
(61,9 \%)\end{array}$ & $\begin{array}{c}1 \\
(1,6 \%)\end{array}$ & $\begin{array}{c}1 \\
(1,6 \%) \\
\end{array}$ & $\begin{array}{c}4 \\
(6,3 \%) \\
\end{array}$ \\
\hline $\mathrm{D}$ & 0 & $\begin{array}{c}1 \\
(1,7 \%)\end{array}$ & $\begin{array}{c}4 \\
(6,7 \%)\end{array}$ & $\begin{array}{c}47 \\
(78,3 \%)\end{array}$ & $\begin{array}{c}1 \\
(1,7 \%)\end{array}$ & $\begin{array}{c}7 \\
(11,7 \%)\end{array}$ \\
\hline $\mathrm{E}$ & 0 & $\begin{array}{c}1 \\
(2,4 \%) \\
\end{array}$ & $\begin{array}{c}7 \\
(16,7 \%) \\
\end{array}$ & $\begin{array}{c}2 \\
(4,8 \%) \\
\end{array}$ & $\begin{array}{c}32 \\
(76,2 \%) \\
\end{array}$ & 0 \\
\hline F & $\begin{array}{c}1 \\
(6,2 \%)\end{array}$ & $\begin{array}{c}2 \\
(12,5 \%)\end{array}$ & $\begin{array}{c}2 \\
(12,5 \%)\end{array}$ & $\begin{array}{c}1 \\
(6,2 \%)\end{array}$ & $\begin{array}{c}6 \\
(37,5 \%)\end{array}$ & $\begin{array}{c}4 \\
(25 \%)\end{array}$ \\
\hline
\end{tabular}

Oznaczenia jak w tabeli 5.

Źródło: opracowanie własne na podstawie danych POLPAN.

Z danych przedstawionych w tabeli 7 wynika, że stabilność zatrudnienia w ramach danych sektorów jest stosunkowo duża i, poza kategorią respondentów, którzy wykonują prace dorywcze, nie spada poniżej $60 \%$. Ponownie należy zauważyć, że analizy nie ukazują przesunięć wewnątrz kategorii. Tak więc zmiana miejsca pracy przez respondenta $\mathrm{z}$ firmy prywatnej A na firmę prywatną $\mathrm{B}$ nie zostanie odnotowana. Znaczącą wartością prezentowanych analiz jest 
jednak mobilność (dobrowolna, lub wymuszona) respondentów pomiędzy kategoriami. Największą ruchliwość zaobserwowano pomiędzy największymi kategoriami: sektorem firm i instytucji państwowych a sektorem firm prywatnych. Warto zauważyć, że są to transfery obustronne. Powiązać je należy z przemianami dokonującymi się w administracji państwowej, dla których sektor firm prywatnych stanowi z jednej strony źródło pracowników o określonych kwalifikacjach, a z drugiej swoisty „,bufor”, w którym schronienie znaleźć mogą zwalniani z instytucji państwowych pracownicy. Wysoki odsetek respondentów, którzy w okresie pomiędzy 1998 a 2003 r. zasilił kategorię osób bezrobotnych, a następnie kategorię emerytów i rencistów, nie zaburzył jednak zasadniczo kierunku oraz siły zmian $\mathrm{w}$ przepływach respondentów między kategoriami w badanych okresach. Pozwala to wysunąć założenie o względnej trwałości ścieżek oraz przemian $\mathrm{w}$ zakresie struktury miejsca zatrudnienia respondentów. Może to stanowić punkt wyjścia do zadania pytania o to, czy mechanizmy i charakter przemian na rynku pracy są względnie niezależne od jego wielkości i liczby dostępnych miejsc pracy.

\section{Podsumowanie}

Prezentowane analizy pozwalają na wyciągnięcie trzech podstawowych wniosków o charakterze ogólnym, dotyczących zmian w sytuacji zatrudnienia oraz miejsca zatrudnienia respondentów.

1. W ciągu 10 lat, jakie obejmują analizowane dane, nastąpiły znaczące przemiany w strukturze dotyczącej sytuacji zatrudnienia respondentów. Przemiany te jednak nie zaburzyły ogólnych tendencji (kierunku i siły) ruchliwości pomiędzy kategoriami miejsca zatrudnienia badanych osób. Można zatem stwierdzić, że przemiany na tym poziomie społecznym (przemiany sytuacji zatrudnienia) są naturalnym procesem opartym na starzeniu się respondentów i naturalnym przechodzeniu z kategorii osób pracujących do kategorii emerytów. Ponadto wystąpienie różnego poziomu bezrobocia nie wpływa zasadniczo na siłę i kierunek przepływów pomiędzy kategoriami miejsca zatrudnienia osób posiadających pracę.

2. Zagrożenie bezrobociem w okresie od 1998 do 2003 r. dotknęło przede wszystkim osób starszych, o czym pozwala wnioskować znaczący odsetek osób z kategorii bezrobotnych, które w 2008 r. znajdowały się już na emeryturze. Prowadzi to do postawienia tezy o pewnej strategii, jaką przyjmowali ci respondenci. Polegała ona na okresowym ,przeczekaniu” czasu po utracie pracy 
(i prawdopodobnych trudnościach w znalezieniu nowego miejsca zatrudnienia) jako zarejestrowani bezrobotni (co wiązać się może z pobieraniem zasiłku oraz ubezpieczeniem zdrowotnym) do momentu osiągnięcia wieku umożliwiającego pobieranie świadczeń emerytalnych.

3. Okresowi wejścia Polski do Unii Europejskiej oraz zmianom w sferze administracji publicznej towarzyszył intensywny rozwój sektora firm prywatnych i zwiększający się udział pracujących w nim respondentów. Zwiększenie tego udziału odbyło się kosztem poziomu zatrudnienia w sektorze państwowym.

Dokonane analizy zmuszają jednak do postawienia kolejnych pytań m.in. o to, w jaki sposób zawód oraz wykształcenie mogą być powiązane z zaobserwowanymi zmianami oraz o to, czy zaobserwowane procesy mają charakter trwały, czy do uchwycenia ich zmian potrzebna jest analiza w dłuższym przedziale czasu. Zawód i wykształcenie respondentów stały się, zwłaszcza po przemianach ustrojowych na początku lat 90., najsilniejszymi korelatami położenia społecznego jednostek (Domański 2004: 217-247; Domański, Sawiński, Słomczyński 2006: 16-18). By odpowiedzieć na te pytania, niezbędne są pogłębione analizy, dla których przedstawione w tym tekście wyniki mogą stanowić bazę i punkt wyjścia.

\section{Bibliografia}

Babbie E. (2004), Badania spoteczne w praktyce, Wydawnictwo Naukowe PWN, Warszawa.

Beck U. (2002), Spoteczeństwo ryzyka. W drodze do innej nowoczesności, SCHOLAR, Warszawa. Domański H. (2004), Struktura społeczna, SCHOLAR, Warszawa.

Domański H., Sawiński Z., Słomczyński K.M. (2006), Nowa klasyfikacja i skale zawodów, IFiS PAN, Warszawa.

Drozdowski R. (2002), Rynek pracy w Polsce: recepcja, oczekiwania, strategie dostosowawcze, Uniwersytet im. Adama Mickiewicza, Poznań.

Janicka K. (2007), Formy zatrudnienia a cechy sytuacji pracy. Niektóre parametry i tendencje zmian na rynku pracy w Polsce, [w:] K.M. Słomczyński (red.), Kariera i sukces, Oficyna Wydawnicza Uniwersytetu Zielonogórskiego, Zielona Góra-Warszawa.

http://www.polpan.org (04.05.2013).

http://www.pracuj.pl/Sprawni-w-pracy-praca-renta-a-praca.htm (11.05.2013).

http://www.stat.gov.pl/gus/5840_677_PLK_HTML.htm (05.05.2013).0 